\title{
Annual Clinicopathological Analysis of Ovarian Tumours at TUTH
}

Sapana Amatya, Geeta Gurung, Ashma Rana

TUTH, IOM, Kathmandu, Nepal.

\begin{abstract}
Objectives: To determine the incidence, epidemiological factors and clinical presentations of different types of ovarian tumours and their correlation with histopathology.

Methods: A descriptive study was conducted in Teaching Hospital, Kathmandu, Nepal in the Department Of Obstetric and Gynaecology from $13^{\text {th }}$ April 2007 to $12^{\text {th }}$ April 2008.

Results: Of the total one hundred and forty six adnexal masses, only 102 were histopathologically proven as ovarian tumours while one was unapproved due to torsion leading to infarction of all ovarian tissues. Benign tumours comprised of 74 (74.5\%), borderline $3(2.9 \%)$ and malignant $23(22.5 \%)$. Mature cystic teratoma, $40.7 \%$ was the commonest benign tumour, whereas serous cystadenocarcinoma (8.7\%) was the commonest ovarian malignancy. Age ranged from 10 to 76 years. Abdominal discomfort, $22.3 \%$ was the commonest presentation followed by abdominal mass (17.5\%). Torsion was observed in $6.8 \%$. Size of the tumour ranged from $2.5 \mathrm{~cm}$ to the largest of giant tumour size of $45 \mathrm{~cm}$. Majority of benign tumours 59 (77.6\%) had unilateral distribution while more than half malignant $12(52.1 \%)$ ones were bilateral. Most cystic tumours $79(76.6 \%)$ were benign and all the mixed tumours $13(12.6 \%)$ observed were malignant. Majority of malignant epithelial tumours presented in late stage of disease where as germ cell tumours presented in early stage.

Conclusion: The commonest ovarian tumour was epithelial followed by germ cell. Mature cystic teratomas were predominant in benign group and serous cystadenocarcinomas in the malignant group. Abdominal discomfort was the major symptom presented by malignant epithelial tumours. Malignant germ cell tumours were presented in earlier age group whereas malignant epithelial tumours more prevalent in postmenopausal group.
\end{abstract}

Key words: Ovarian tumours, histopathology, epithelial, germ cell, benign, borderline malignant.

\section{Introduction}

Ovarian cancer is the second most common genital tract malignancy accounting for $25 \%$ gynaecological malignancies. It accounts for $6-7.5 \%$ of all cancers and is the fifth most common form of malignancy in women in the United States or sixth worldwide being highest in the Scandinavian countries $(14.9 / 100,000)$ and lowest in Japan $(2.7 / 100,000) .{ }^{1-4}$ It is one of the leading cause of death from gynaecological malignancies, approximately in $50 \%$ of deaths that occurs at all the age. ${ }^{5}$

A detailed study on this subject in Nepal has not been conducted to the best of our knowledge this study titled "A clinicopathological analysis of ovarian tumours was undertaken to study the incidence and clinicopathological correlation of ovarian tumours.

\section{Methods}

A descriptive study of one year duration $\left(13^{\text {th }}\right.$ April 2007 to $12^{\text {th }}$ April 2008) was conducted in the Department of Obstetrics and Gynaecology. IOM, TUTH on all the cases of ovarian tumour admitted during the period.

\section{Results}

Of the total of 926 gynaecological admissions, adnexal masses were 146. In which 103 were ovarian tumours and non tumourous conditions were 43 . Of the total 103 ovarian tumours, histopathologically proven

Correspondence

Dr. Sapana Amatya. MD

Sr. Med. Officer, Maternity and Womens Hospital, Thapathali, Kathmandu Nepal.

vaidyasujan@yahoo.co.uk 
Table 1. Types of ovarian tumours according to age

\begin{tabular}{|c|c|c|c|c|c|c|c|c|}
\hline Ovarian tumour & Types & $10-19 \mathrm{yrs}$ & 20-29yrs & 30-39yrs & $40-49 y r s$ & $50-59 \mathrm{yrs}$ & $60-69 y r s$ & $>70 \mathrm{yrs}$ \\
\hline Epithelial & Benign & 1 & 7 & 10 & 6 & 4 & 2 & 2 \\
\hline \multirow[t]{2}{*}{$(\mathrm{N}=51)$} & Borderline & & & & 2 & & 1 & \\
\hline & Malignant & & 2 & 3 & 3 & 3 & 4 & 1 \\
\hline Sex Cord & Benign & & & & & & 1 & \\
\hline$(\mathrm{N}=2)$ & Malignant & & & & & & 1 & \\
\hline Germ cell & Benign & 7 & 14 & 13 & 6 & 3 & & \\
\hline$(\mathrm{N}=47)$ & Malignant & 2 & 1 & & & 1 & & \\
\hline Miscellaneous & Benign & & & & & & & \\
\hline$(\mathrm{N}=2)$ & Malignant & & 1 & & 1 & & & \\
\hline
\end{tabular}

Table 2a. Clinical features with the type of ovarian fumours.

\begin{tabular}{|c|c|c|c|c|c|}
\hline $\mathbf{C} / \mathbf{F}$ & Total no & $\begin{array}{l}\text { Types of ovarian } \\
\text { tumour }\end{array}$ & Benign & Borderline & Malignant \\
\hline Mass per abdomen & 2 & Serous & 2 & & \\
\hline \multirow[t]{7}{*}{$\mathrm{N}=18(17.5 \%)$} & 5 & Mucinous & 3 & 1 & 1 \\
\hline & 1 & YST & & & 1 \\
\hline & 8 & MCT & 8 & & \\
\hline & 1 & MCT with & & & 1 \\
\hline & & malignant trans & & & \\
\hline & & formation & & & \\
\hline & 1 & Mixed germ cell & & & 1 \\
\hline Abdominal discomfort & 12 & Serous & 4 & 1 & 7 \\
\hline \multirow[t]{4}{*}{$\mathrm{N}=23(22.3 \%)$} & 3 & Mucinous & 2 & & 1 \\
\hline & 2 & Endometroid & & & 2 \\
\hline & 1 & YST & & & 1 \\
\hline & 5 & MCT & 5 & & \\
\hline Acute pain abdomen & 2 & Serous & 2 & & \\
\hline \multirow[t]{2}{*}{$\mathrm{N}=7(6.8 \%)$} & 2 & Mucinous & 2 & & \\
\hline & 3 & MCT & 3 & & \\
\hline Acute on chronic pain & 1 & Inconclusive & & & \\
\hline \multicolumn{6}{|l|}{$\mathrm{N}=1(0.9 \%)$} \\
\hline Chronic pain abdomen & 3 & Serous & 2 & & 1 \\
\hline \multicolumn{6}{|l|}{$\mathrm{N}=16(15.5 \%)$} \\
\hline & 2 & Mucinous & 1 & & 1 \\
\hline & 2 & Endometroid & & & 2 \\
\hline & 8 & $\mathrm{MCT}$ & 8 & & \\
\hline & 1 & Monodermal & 1 & & \\
\hline
\end{tabular}


Table 2b. Clinical features with the type of ovarian tumours

\begin{tabular}{|c|c|c|c|c|c|}
\hline $\mathrm{C} / \mathrm{F}$ & Total no & $\begin{array}{l}\text { Types of ovarian } \\
\text { tumour }\end{array}$ & Benign & Borderline & Malignant \\
\hline Gastro intestinal & 3 & Serous & 2 & & 1 \\
\hline symptoms & 1 & Mucinous & 1 & & \\
\hline \multirow[t]{2}{*}{$\mathrm{N}=14(13.6 \%)$} & 9 & MCT & 9 & & \\
\hline & 1 & Krukenberg & & & 1 \\
\hline Menstrual & 1 & Brenner & 1 & & \\
\hline disturbance & 1 & AGCT & & & 1 \\
\hline $\mathrm{N}=4(3.9 \%)$ & 2 & $\begin{array}{l}\text { MCT(in association } \\
\text { with adenomyosis) }\end{array}$ & 2 & & \\
\hline $\begin{array}{l}\text { Dysmenorrhoea } \\
\mathrm{N}=3(2.9 \%)\end{array}$ & 3 & Serous & 3 & & \\
\hline Pressure symptoms & 1 & Serous & 1 & & \\
\hline $\mathrm{N}=2(1.9 \%)$ & 1 & $\mathrm{MCT}$ & 1 & & \\
\hline Incidental & 5 & Serous & 4 & 1 & \\
\hline \multirow[t]{2}{*}{$\mathrm{N}=11(10.7 \%)$} & 5 & $\mathrm{MCT}$ & 5 & & \\
\hline & 1 & Krukenberg & & & 1 \\
\hline Asymptomatic & 3 & MCT & 3 & & \\
\hline $\mathrm{N}=5(4.9 \%)$ & 2 & Serous & 2 & & \\
\hline
\end{tabular}

ovarian tumours were 102 , one was unproven due to necrosis of ovarian tissue as a result of torsion.

Benign ovarian tumours were $76(74.5 \%)$, borderline, 3 $(2.94 \%)$, and malignant ovarian tumours were 23 $(22.5 \%)$. The commonest ovarian tumour observed was epithelial $51(50 \%)$ followed by germ cell tumour 47 (46.08\%) out of 102 histopathologically proven ovarian tumours. Mature cystic teratoma $42(55.3 \%)$ was the commonest benign ovarian tumour. Serous cystadenocarcinoma $9(39.1 \%)$ was the most common malignant tumour.

Benign epithelial tumours $10(19.6 \%)$ were most prevalent in the age range of $30-39$ years. Malignant epithelial tumours 4 (7.84\%) were most prevalent in the age range of 60-69 years. Both sex cord stromal tumours were observed in postmenopausal age group. Majority of the benign germ cell tumours 14 (29.8\%) were prevalent in 20-29 years and 2 out of 4 malignant tumours were observed in 10-19 years. Miscellaneous tumours comprising of krukenberg were observed in the reproductive age group. (Table1)

Acute abdominal pain (6.8\%) due to torsion was presented by $9.2 \%$ of benign ovarian tumours while in one case; there was acute exacerbation on chronic pain, also due to torsion of the pedicle. HPE was inconclusive due to infarction and necrosis of the ovarian tissues. Forty eight percent of the malignant tumours presented with abdominal discomfort followed by chronic pain abdomen (17.4\%) and mass per abdomen (17.4\%). (Table $2 \mathrm{a} / \mathrm{b}$ )

Out of 16 malignant epithelial tumours, had presented with abdominal discomfort and majority $(\mathrm{N}=9)$ presented in advanced stage of disease. (Table $3 \mathrm{a} / \mathrm{b}$ ) Majority of germ cell tumours, 3 out of 4 presented with mass abdomen. All of the malignant germ cell tumours of ovary presented in early stage (Stage I $\mathrm{A}-\mathrm{IC})$

Maximum numbers of benign tumour were less than 10 $\mathrm{cm}$ and malignant were more than $10 \mathrm{~cm}$.

Smallest size $(2.5 \mathrm{~cm})$ of the tumour observed was serous cystadenoma while the largest of giant size $(45 \times 36 \mathrm{~cm})$ was seen in a mucinous cystadenocarcinoma. Majority of benign tumours $59(77.6 \%)$ had unilateral distribution. Of the total of 23 malignant ovarian tumours, $12(52.1 \%)$ had bilateral distribution. Total numbers of cystic tumours observed were 79 (76.6\%).Majority of cystic tumours $74(93.7 \%)$ were benign and 3(3.8\%) were of borderline type. Only $2.5 \%$ of malignant ovarian tumours (mucinous cystadenocarcinoma) were cystic in nature. Total number of mixed ovarian tumours were 13 (12.6\%).All of the mixed ovarian tumours were of malignant type Total numbers of solid tumours were seen in $4(3.9 \%)$. Of the solid tumours half $(50 \%)$ were malignant and half $(50 \%)$ were benign. 
Table 3a. Clinical details of malignant epithelial ovarian tumours

\begin{tabular}{|c|c|c|c|c|c|}
\hline Types of tumour & $\begin{array}{l}\text { Age } \\
(\text { yrs })\end{array}$ & Symptoms & $\begin{array}{c}\text { Surgical Stage } \\
\text { of tumour }\end{array}$ & Types of surgery & $\mathbf{F} / \mathbf{u}$ \\
\hline \multirow[t]{9}{*}{$\begin{array}{l}\text { Serous cystadeno } \mathrm{Ca} \\
(\mathrm{N}=9)\end{array}$} & 32 & $\begin{array}{l}\text { Abdominal } \\
\text { discomfort }\end{array}$ & IIIC & $\begin{array}{l}\text { Staging TAH BSO } \\
\text { with omental biopsy }\end{array}$ & $\mathrm{CT}(\mathrm{PC})$ \\
\hline & 34 & $\begin{array}{l}\text { Abdominal } \\
\text { discomfort }\end{array}$ & IV & $\begin{array}{l}\text { Staging laparotomy } \\
\text { with omental biopsy }\end{array}$ & $\begin{array}{l}\text { CT with } \\
\text { Interval } \\
\text { cytoreduction }\end{array}$ \\
\hline & 41 & " & IIIC & " & \\
\hline & 42 & $"$ & IIIC & $"$ & expired \\
\hline & 53 & $\begin{array}{l}\text { Menstrual } \\
\text { disturbances } \\
\text { (Association } \\
\text { with fibroid) }\end{array}$ & IA & TAHBSO & No F/U \\
\hline & 55 & G.I.symptoms & IIIB & $\begin{array}{l}\text { Staging TAH BSO } \\
\text { with mental biopsy }\end{array}$ & $\mathrm{CT}(\mathrm{PC})$ \\
\hline & 60 & $\begin{array}{l}\text { Abdominal } \\
\text { discomfort }\end{array}$ & $\mathrm{IB}$ & $\begin{array}{l}\text { Staging TAH BSO } \\
\text { with omental biopsy }\end{array}$ & No F/U \\
\hline & 64 & $\begin{array}{l}\text { Abdominal } \\
\text { discomfort }\end{array}$ & IV & Operation not done & Expired at $\mathrm{CCU}$ \\
\hline & 65 & $\begin{array}{l}\text { Abdominal } \\
\text { discomfort }\end{array}$ & IIIC & $\begin{array}{l}\text { Staging laparotomy } \\
\text { with omental biopsy }\end{array}$ & $\mathrm{CT}(\mathrm{PC})$ \\
\hline \multirow{4}{*}{$\begin{array}{l}\text { Mucinous cyst } \\
\text { adeno } \mathrm{Ca} \\
(\mathrm{No}=3)\end{array}$} & 22 & Abdominal & IA & USO+LSCS & $\mathrm{CT}(\mathrm{PC})$ \\
\hline & & $\begin{array}{l}\text { Discomfort } \\
\text { (pregnancy) }\end{array}$ & & & $\begin{array}{l}\text { Interval } \\
\text { cytoreduction }\end{array}$ \\
\hline & 32 & Mass+UVP & IA & $\begin{array}{l}\text { VHPFR with } \\
\text { enucleation of cyst }\end{array}$ & No F/U \\
\hline & 76 & $\begin{array}{l}\text { Abdominal } \\
\text { Discomfort }\end{array}$ & IA & $\begin{array}{l}\text { Staging TAH BSO } \\
\text { with omental biopsy }\end{array}$ & No F/U \\
\hline \multirow[t]{4}{*}{$\begin{array}{l}\text { Endometroid } \mathrm{Ca} \\
(\mathrm{N}=4)\end{array}$} & 29 & $\begin{array}{l}\text { Abdominal } \\
\text { discomfort }\end{array}$ & IA & USO & $\begin{array}{l}\text { Staging TAH BSO } \\
\text { with omental biopsy }\end{array}$ \\
\hline & 42 & $\begin{array}{l}\text { Abdominal } \\
\text { discomfort }\end{array}$ & IIIC & $\begin{array}{l}\text { Staging with } \\
\text { omental biopsy }\end{array}$ & $\begin{array}{l}\text { CT } \\
\text { (Bharatpur) }\end{array}$ \\
\hline & 46 & Pain abdomen & IIIC & $\begin{array}{l}\text { Staging TAH BSO } \\
\text { with omental biopsy }\end{array}$ & $\mathrm{CT}(\mathrm{PC})$ \\
\hline & 58 & Pain abdomen & IC & $\begin{array}{l}\text { Staging TAH BSO } \\
\text { with omental biopsy }\end{array}$ & No F/U \\
\hline
\end{tabular}

Table 3b. Clinical details of sex cord stromal, malignant germ cell and Krukenberg tumours

\begin{tabular}{|c|c|c|c|c|c|}
\hline Types of tumour & Age(yrs) & Symptoms & Stage of tumour & Types of surgery & $\mathbf{F} / \mathbf{u}$ \\
\hline Adult GCT (N=1) & 60 & $\begin{array}{l}\text { Menstrual } \\
\text { disturbances }\end{array}$ & $\begin{array}{l}\text { StagingTAH BSO } \\
\text { with omental biopsy }\end{array}$ & No F/U & \\
\hline \multirow[t]{2}{*}{ YST (N=2) } & 12 & Mass abdomen & IA & $\begin{array}{l}\text { USO+omental } \\
\text { biopsy }\end{array}$ & $\mathrm{CP}(\mathrm{BEP})$ \\
\hline & 14 & $\begin{array}{l}\text { Abdominal } \\
\text { discomfort }\end{array}$ & IC & $\begin{array}{l}\text { USO with } \\
\text { omental biopsy }\end{array}$ & $\mathrm{CP}(\mathrm{BEP})$ \\
\hline $\begin{array}{l}\text { Mixed Germ Cell }(\mathrm{N}=1) \\
\text { YST } 90 \%+\text { MCT-10\% }\end{array}$ & & Mass abdomen & IA & $\begin{array}{l}\text { USO with } \\
\text { omental } \\
\text { biopsy }\end{array}$ & No F/U \\
\hline $\begin{array}{l}\text { MCT.malignant } \\
\operatorname{transformation}(\mathrm{N}=1)\end{array}$ & 50 & Mass abdomen & - & $\begin{array}{l}\text { StagingTAH } \\
\text { BSOwith } \\
\text { omental biopsy }\end{array}$ & No-F/U \\
\hline \multirow[t]{2}{*}{ Krukenberg $(\mathrm{N}=2)$} & 47 & G I symptoms & IB & $\begin{array}{l}\text { StagingTAH } \\
\text { BSO with } \\
\text { omental biopsy }\end{array}$ & $\begin{array}{l}\mathrm{F} / \mathrm{U} \text { at } \\
\text { Bharatpur }\end{array}$ \\
\hline & 25 & incidental & IC & $\begin{array}{l}\text { StagingTAH BSO } \\
\text { with Omental biopsy }\end{array}$ & $\mathrm{CT}(\mathrm{PC})$ \\
\hline
\end{tabular}


Table 4. Ovarian fumours associated with other gynaecological pathology

\begin{tabular}{|c|c|c|c|c|c|}
\hline $\begin{array}{l}\text { Clinical } \\
\text { conditions }\end{array}$ & $\begin{array}{l}\text { Types of Ovarian } \\
\text { Tumours }\end{array}$ & Benign & Malignant & borderline & No \\
\hline \multirow[t]{2}{*}{ Fibroid Uterus } & Serouscysadenoma & 1 & 1 & & 4 \\
\hline & MCT & 2 & & & \\
\hline Adenomyosis & MCT & 2 & & & 2 \\
\hline \multirow[t]{2}{*}{ UVP } & Serous cystadenoma & 1 & & & 2 \\
\hline & Mucinous cys adeno $\mathrm{Ca}$ & & 1 & & \\
\hline $\begin{array}{l}\text { Pyometra due to } \\
\text { Ca cervix } \\
\text { (endometroid adeno } \mathrm{Ca} \text { ) }\end{array}$ & Serous cystadenoma & 1 & & & 1 \\
\hline Total & & 7 & 2 & & 9 \\
\hline
\end{tabular}

Benign ovarian tumours like serous cystadenoma was associated with endometroid adenocarcinoma of cervix, while ovarian malignancy like serous cystadenocarcinoma and mucinous adenocarcinoma was associated with fibroid uterus and uterovaginal prolapse respectively. (Table 4.)

Tumour associated with pregnancy was found in 21 to 39 years, in primi $(55.5 \%)$ and multipara which were discovered in 5 to 39 weeks period of gestation, the nature of tumour being benign $(88.8 \%)$, their presentation being torsion $44.4 \%$. There was a case mucinous cyst adenocarcinoma in pregnancy.

\section{Discussion}

The incidence, clinical appearance and the behavior of the different types of ovarian tumours are extremely variable. It becomes difficult to diagnose the nature of the ovarian tumours pre-operatively only on the basis of clinical examination, serum markers, imaging, peritoneal fluid cytology indicating the necessity of histopathological correlation.

Also all the tumor like conditions are not ovarian tumours, thus pointed by this study, 102 being the histologically proven ovarian tumours, 43 of the adnexal masses being non neoplastic cystic lesions like endometroitic cysts, fimbrial cyst, corpus luteal cyst, follicular cysts, and hydatid cyst, those being excluded from the study.

\section{Histological types of ovarian tumours}

Benign ovarian tumours accounted for $76(74.5 \%)$ followed by malignant ovarian tumours $23(22.5 \%)$ and borderline tumours $3(2.94 \%)$ and similar findings have been quoted..$^{6-8}$ Epithelial tumours accounted for 51 (50\%), followed by germ cell tumours 47 (45.08\%), sex cord stromal tumours and miscellaneous tumours of $2(1.96 \%)$ each which coincided to others. ${ }^{6,9}$

Among the benign tumours, serous cystadenoma (43.1\%) was the commonest benign epithelial tumour followed by mucinous cystadenoma (17.6\%) that goes in favour with other study. ${ }^{10}$ Boderline tumour are also noted as in other studies. 11-13. Mucinous cystadenocarcinoma has been reported as the next common epithelial malignancy following serous cystadenocarcinoma. ${ }^{12-14}$

Sex-cord stromal tumours, like Fibroma and Granulosa cell tumour are rare ${ }^{15,16}$

Mature cystic teratomas $42(89.3 \%)$ is by and large the most common Germ cell ovarian tumor as alignment with other studies. ${ }^{15,17-19}$ Monodermal tumour comprising Struma ovarii accounted for $2.1 \%$ in our study. ${ }^{20-21}$ Malignant transformation of mature cystic teratoma or squamous cell carcinoma arising a in MCT is a rare finding quoted to be $1-2 \%$ was seen in our study too. ${ }^{22}$ While yolk sac tumour (4.25\%) was noted as the most common malignant germ cell tumour, $8 \%$ of malignant germ cell tumours were mixed, mixture formed by dysgerminoma and endodermal sinus tumour. ${ }^{23}$ Present observation showed $90 \%$ of endodermal sinus tumour with $10 \%$ of mature cystic teratoma in a case of mixed germ cell tumour.

Secondary Krukenberg tumours (1.94) came as an interesting finding.

\section{Types of ovarian tumours according to age}

Ovarian tumours can occur at all age ranging from 7 months to seventy two years in ours it was 11 years to 76 years (Table 2). ${ }^{24,25}$ Both the sex cord stromal tumours were found in postmenopausal age group. In contrary to the epithelial ovarian tumours, malignant germ cell tumours occurred at a premenarchal age. ${ }^{26}$ Sqamous cell carcinoma arising in mature cystic teratoma (MCT) was observed in 57 year. ${ }^{27}$ Of the two Krukenberg tumours, both were seen under 50 and at late age. ${ }^{28}$

\section{Clinical presentation}

Incidental findings were seen in $8.7 \%$ of the tumours, one of them being a case of Krukenberg in her follow 
up, who had completion of chemotherapy for adenocarcinoma of stomach. Rest of the incidental findings were during caesarian section, laparatomy for ectopic pregnancy and general health check up (pelvic examination and USG).

Abdominal pain / discomfort, bloating sensation, GI upsets, and pressure symptoms as urinary frequency, constipation, palpable mass major presentations. ${ }^{29}$ Because of endometrial hyperplasia, atypia, and endometrial carcinoma Granulosa cell tumour presented with postmenopausal bleeding. ${ }^{30}$ Majority of malignant germ cell tumours were presented with mass per abdomen while abdominal mass is more likely a presentation. ${ }^{26}$

\section{Size of the tumour}

Size of the tumour as big as $45 \mathrm{~cm}$ in the present study in a case of mucinous cytadenocarcinoma stage IA measuring $45 \times 38 \mathrm{~cm}$ in a 76 years old lady and mucinous cystadenoma measuring $35 \times 45 \times 50 \mathrm{~cm}$ denoting giant cell tumour. $^{31}$

\section{$U / L$ or $B / L$ distribution of ovarian tumour}

Benign ovarian tumours $(77.6 \%)$ were unilateral and malignant $(52.1 \%)$ were bilateral.

\section{Consistency}

Of the cystic tumours, $93.7 \%$ were benign. Mature cystic teratoma $53.4 \%$ was the commonest although Mucinous cystadenocarcinoma (2.5\%) formed little exception. Half of the solid tumours were benign Brenner and Fibroma one each. Mixed consistency was also malignant and the only solid tumours was Krukenberg tumours. ${ }^{32}$

\section{Ovarian tumours associated with pregnancy}

The incidence of ovarian tumours during pregnancy is $0.22 \%$ which is comparable to other series. ${ }^{33-35}$

Acute abdomen $(77.7 \%)$ was the presentation due to torsion (44.4\%). Ovarian malignancy is the second commonest gynaecological cancer detected during pregnancy.

\section{Conclusion}

The commonest ovarian tumour was epithelial followed by germ cell. Mature cystic teratomas were predominant in benign group and serous cystadenocarcinomas in the malignant group. Abdominal discomfort was the major symptom presented by malignant epithelial tumours. Malignant germ cell tumours were presented in earlier age group whereas malignant epithelial tumours more prevalent in postmenopausal group.

\section{References}

1. Crum CP. The female genital tract. In Robbin's Pathologic Basis of Disease. $7^{\text {th }}$ ed. New York: W.B. Saunders company; 2004: 1035-1092.

2. Baker TR, Piver SM. Etiology, biology and epidemiology of ovarian cancer. Seminars in Surgical Oncology 1994; 10; 242-48.

3. Van Nagell JR, Gershenson DM. Ovarian Cancer: Etiology, Screening, and Surgery. In Te Linde's Operative Gynecology. 9 ${ }^{\text {th }}$ ed. Philadelphia: Lippincott Williams \& Wilkins; 2003: 1487-1522.

4. Shrestha B. Gynecological Oncology Unit. Annual Report 2003, B.P. Koirala Memorial Cancer Hospital, 13-14.

5. Yancik R. Ovarian cancer, age contrasts in incidence, histology, disease stage at diagnosis, and mortality. Cancer 1993; 71: 517-23.

6. Ahmed M, Malik T M, Afzal S, Mubarik Azhar. Clinicopathological study of 762 ovarian neoplasms. Pakistan J Pathol 2004; 15(4):147-52

7. Gupta N, Bisht D, Agrawal AK, Sharma VK. Retrospective and prospective study of ovarian tumours and tumour like lesions. Indian Journal Of pathology and microbiology 2007; 50 (3): 525 $-27$.

8. Pilli Ganga S, Suneeta KP, Dhaded AV, Yenin VV. Ovarian tumours: A study of 282 cases. Journal of the Indian Medical Association 2002;100 (7) :420-24.

9. Ahmad Z, Kayani N, Hasan S, Muzaffar S, Gill M . Histological pattern of ovarian neoplasm. 2000; 50 (12): 416-9

10. Shah $\mathrm{S}$, Hishikar Va. Incidence and management of Ovarian tumours. 2008; 50 (1):30-3.

11. Maheshwori V, Tyagi SP, Saxena K, Tyagi N, Sharma R, Aziz F, Hameed F. Surface Epithelial Tumours Of The Ovary. Indian J. Pathol. Microbiol 1994; 37 (1): 75-85

12. Sarkar R. Ovarian neoplasm-A 14 year study. J. of Obstet \& Gynaecology of India 1996; 46 (1):156-59.

13. Khan AA, Lukman M, Jamal N, Mushtaq S. Clinicopathological analysis of ovarian tumours. Pak J Pathol 2005; 16(1):28-32

14. Ahmad Z, Kayani N, Hasan S, Muzaffar S, Gill M . Histological pattern of ovarian neoplasm. 2000; 50 (12): 416-9 Jamal S, Mamoon N, Mushtaq S, Luqman M, Moghai S.

15. Mukherjee C, Dasgupta A, Ghosh R N..,Sengupta J. Ovarian tumours - A ten years study. J of Obstet \& Gynaecology of India 1991; 41 (5): 691-96.

16. Chua SI,Tan KT,Lim-Tan S, TH.A Clinical review of Granulosa Cell Tumours of the Ovary cases in KKH Singapoor Med J 2001;42(5):203-07

17. Amatya A Rana A, Gurung G. Ovarian tumours in childhood and adolescents - our eight years experiences.NJOG 2008;3(1): 39-2. 
18. Sah SP, Uprety D, Rani S. Germ cell tumours of the ovary: a clinicopathlogic study of 121 cases from Nepal.J Obstet Gynaecol res 2004;30 (4):3038.

19. Sahu L, Mallik RN, Nanda M, Sethy CR, Dash S. Germ cell tumours of ovary-Review of 46 cases. . Journal of Obstetrics and Gynaecology of India June 1990;40 (3):446-50.

20. Sheikh MA, Akhtar J, Batool T, Naqvi R, Taqvi R, Jalil S, Soomro A, Ahmed A, Mirza F. A study of ovarian lesions in pre-menarche girls. Coll Physicians Surg Pak. 2007 Mar ;17 (3):162-6

21. Jamal S, Mamoon N, Mushtaq S, Luqman M, Moghai S.The pattern of gynaecv ologial malignancy in 968 cases from Pakistan. Ann Saudi Med 2006;26 (5):382-84.

22. Kikkawa F, Nawa A, Ishikawa H, kuzuo K, Suganuma N, Hattori S, Furui K, Kawai M, Arii Y. Diagnosis of Squamous Cell Carcinoma Arising from Mature Cystic Teratoma of the Ovary. American Cancer society 1998; 82(11):2249-55.

23. David M, Gersshenson ,MD, Gerard D J , MD, Larry J. MD, and Felix N. Rutledge, MD. Mixed Germ Cell Tumours Of The Ovary Obstetrics \& Gynecology 1984; 64 (2):200-206.

24. Chauhan AS, Kapadia AS, Desai AF, Patel SM,Dave KS. Mucinous Tumours Of Ovary. J. of obst. \& Gyn. Of India 2001; 51 (6) : 138-42.

25. Malmstrom H, Hogberg T, Risberg B, and Simonsen E. Granulosa Cell Tumour of the Ovary: Prognostic factors and outcome Gynaecology Oncology 1994;52;50- 55.

26. Kundu S, Dutta CR, Pati S, Majumdar A.The incidence and management of malignant ovarian tumours in girls upto 20 years of age. J Obstet Gynaecol Ind 2003; 53 (4): 375-379
27. Santos SD, Mok E, Iasonos A, Park K, A robort, Aghajanian SC, Alektiar K, Barakat RR, AbuRustum NR. Squamous cell carcinoma arising in mature cystic teratoma of the ovary:A case series and review of literature.Gynaecological Oncology 2007; 105:321-24.

28. Taner T, Burcu A, Sevgi K, Nurettin B, Gokhan T, Ozlem K, Zuhai E. Analysis of metastatic ovarian tumours from extragenital primary sites. Tumri 2006;92:491-95.

29. Sharma T, Mohsin S, Khan AA, Hakim S. Cytohistomorphological study of ovarian tumours . J Of Obstet \& Gynaecology of India.1981;34:65-9

30. H Fox, Agrawal K, Langley F A. A Clinicopathological Study Of 92 Cases Of Granulosa Cell Tumour Of The Ovary With Special Reference To The factors Influencing Prognosis Cancer 1975;35: 231-4

31. Farinetti A, Buttazzi A, Tazzioli G, Saviano L, Saviano M. Giant ovarian cyst. A case weighing $23 \mathrm{~kg}$ (50.6 lb). Minerva Chir. $2003 \mathrm{Apr}$; 58(2):261-5.

32. Tyagi SP, Maheswari V, Tyagi N, Saxena K, Sharma R, Hameed F. Solid tumours of the Ovary J Indian Med Assoc 1993; 91 (9):227-229

33. EI-Yahia AR, Rahman J, Rahman MS, Suleiman A. Ovarian tumours in pregnancy. Aust NZ J Obstet Gynecol 1991;324-30.

34. Buttery BW, Beischer NA, Fortune DW, Macafee CAJ. Ovarian tumours in pregnancy. Med J Aust 1973;1:345-49.

35. Kumari I, Kaur S, Harsh M and Huria A. Adnexal masses in pregnancy : A 5 year review. Aust NZ J .Obstet Gynecol 2006;46: 52-4. 